\title{
The Oslo definitions for coeliac disease and related terms
}

\author{
Jonas F Ludvigsson, ${ }^{1,2}$ Daniel A Leffler, ${ }^{3}$ Julio C Bai, ${ }^{4}$ Federico Biagi, ${ }_{1}^{5}$ Alessio Fasano, ${ }^{6}$ \\ Peter H R Green, ${ }^{7}$ Marios Hadjivassiliou, ${ }^{8}$ Katri Kaukinen, ${ }^{9}$ Ciaran P Kelly, ${ }^{3}$ \\ Jonathan N Leonard, ${ }^{10}$ Knut Erik Aslaksen Lundin, ${ }^{11}$ Joseph A Murray, ${ }^{12}$ \\ David S Sanders, ${ }^{13,14}$ Marjorie M Walker, ${ }^{14}$ Fabiana Zingone, ${ }^{15}$ Carolina Ciacci ${ }^{16}$
}

- An additional appendix is published online only. To view this file please visit the journa online (http://dx.doi.org/10 1136/gutjnl-2011-301346)

For numbered affiliations see end of article.

\section{Correspondence to} Dr Daniel Leffler, Division of Gastroenterology, Beth Israel Deaconess Medical Center, 330 Brookline Ave, Boston, MA 02215, USA:

dleffler@caregroup.harvard.edu

Revised 17 January 2012 Accepted 20 January 2012 Published Online First 16 February 2012

\section{ABSTRACT}

Objective The literature suggests a lack of consensus on the use of terms related to coeliac disease (CD) and gluten. Design A multidisciplinary task force of 16 physicians from seven countries used the electronic database PubMed to review the literature for CD-related terms up to January 2011. Teams of physicians then suggested a definition for each term, followed by feedback of these definitions through a web survey on definitions, discussions during a meeting in Oslo and phone conferences. In addition to 'CD', the following descriptors of $C D$ were evaluated (in alphabetical order): asymptomatic, atypical, classical, latent, non-classical, overt, paediatric classical, potential, refractory, silent, subclinical, symptomatic, typical, CD serology, CD autoimmunity, genetically at risk of $\mathrm{CD}$, dermatitis herpetiformis, gluten, gluten ataxia, gluten intolerance, gluten sensitivity and gliadin-specific antibodies.

Results CD was defined as 'a chronic small intestinal immune-mediated enteropathy precipitated by exposure to dietary gluten in genetically predisposed individuals'. Classical CD was defined as 'CD presenting with signs and symptoms of malabsorption. Diarrhoea,

steatorrhoea, weight loss or growth failure is required.' 'Gluten-related disorders' is the suggested umbrella term for all diseases triggered by gluten and the term gluten intolerance should not to be used. Other definitions are presented in the paper.

Conclusion This paper presents the Oslo definitions for CD-related terms.

\section{INTRODUCTION}

Coeliac disease (CD) is a chronic small intestinal immune-mediated enteropathy precipitated by exposure to dietary gluten in genetically predisposed people. Although symptoms and signs of CD have been recognised for more than 100 years, it was in the 1940s that the Dutch paediatrician Dicke established a link between the protein component of wheat (gluten) exposure and CD. ${ }^{1}$ $\mathrm{CD}$ and related diseases are now common chronic diseases in children and adults, and increased diagnosis has led to a proliferation of research activities. As with many other chronic conditions, the boundaries of $\mathrm{CD}$ are not always clear, with the consequence that there is considerable confusion and a lack of consensus regarding diagnostic criteria of $\mathrm{CD}$ and related conditions.

\section{Significance of this study}

What is already known on this subject?

- There is a lack of consensus on the use of terms related to coeliac disease (CD) and gluten.

- Variability in the use of terminology has led to difficulty when comparing and evaluating clinical studies and research findings.

\section{What are the new findings?}

- The panel reached agreement on the definition of terms related to $C D$ and/or gluten currently in use in clinical practice and research.

- Some terms in current use should be abandoned because they are outdated or misleading.

\section{How might it impact on clinical practice in the} foreseeable future?

- Uniform definitions for common terms relating to CD will improve communication among researchers, clinicians and the general public, and will ensure that research is conducted and reported in a consistent manner.

The first consensus definition of $\mathrm{CD}$ was published in Acta Paediatrica in $1970 .^{2}$ This publication defined $\mathrm{CD}$ as a permanent condition of gluten intolerance with mucosal flattening that reversed on a gluten-free diet (GFD) and then relapsed on re-introduction of gluten. Although the definition of $\mathrm{CD}$ has undergone minor changes since $1970,{ }^{3} 4$ consensus definitions have been restricted to $\mathrm{CD}$. However, the scientific community has come to recognise that there is a spectrum of disorders related to gluten ingestion.

Due to a lack of common definitions for the spectrum of terms and disorders related to $\mathrm{CD}$, a multidisciplinary task force of 16 physicians from seven countries with particular expertise in diagnosis and treatment of CD proposes the following definitions for the variety of vague and often confusing terms currently in use in the literature. These definitions are based on thorough literature reviews (table 1), a discussion in Oslo at the 14th International Coeliac Disease Symposium in June 2011, and agreement on consensus statements by a web survey and phone conferences. We refer to our definitions as the 'Oslo definitions'. 
Table 1 Terms evaluated for this review

\begin{tabular}{|c|c|}
\hline Term & $\begin{array}{l}\text { PubMed hits until } \\
\text { January 2011* }\end{array}$ \\
\hline \multicolumn{2}{|l|}{ Defined } \\
\hline Coeliac disease (CD) $\dagger$ & 14843 \\
\hline Asymptomatic CD & 39 \\
\hline Classical CD & 10 \\
\hline Paediatric classical $\mathrm{CD} \dagger$ & - \\
\hline Non-classical & 3 \\
\hline Potential CD & 33 \\
\hline Refractory CD & 109 \\
\hline Subclinical CD & 43 \\
\hline Symptomatic CD & 26 \\
\hline CD autoimmunity $\ddagger$ & 16 \\
\hline Genetically at risk of $\mathrm{CD} \dagger$ & - \\
\hline Dermatitis herpetiformis $\dagger$ & 2759 \\
\hline Gluten $†$ & 8879 \\
\hline Gluten ataxia & 28 \\
\hline Non-coeliac gluten sensitivity & 85 \\
\hline Gliadin-specific antibodies§ & 5 \\
\hline Overt CD & 10 \\
\hline Gluten-related disorders & 12 \\
\hline \multicolumn{2}{|l|}{ Discouraged } \\
\hline Atypical CD & 13 \\
\hline Latent CD & 78 \\
\hline Typical CD & 11 \\
\hline Gluten intolerance & 244 \\
\hline Gluten sensitivity & 241 \\
\hline Silent CD & 80 \\
\hline CD serology 9 & 15 \\
\hline
\end{tabular}

*We searched PubMed for the period 1 January 1900 to 31 January 2011. Individual authors then examined papers deemed most relevant. When the phrase 'coeliac disease' is part of the definition, we searched PubMed for the relevant term and coeliac disease (British and American spelling). For example, 'silent coeliac disease' [All Fields] OR 'silent coeliac disease' [All Fields] AND ('1900/01/01' [PDAT]: '2011/01/31' [PDAT]).

†For these terms, our literature review was entirely based on expert consensus of the literature because it was beyond the scope of this paper to review all papers identified through PubMed (or as in the case of 'paediatric classical CD' there were no hits).

$\ddagger$ We searched for 'coeliac disease autoimmunity' and 'coeliac autoimmunity' (British and American spelling).

$\S A$ search for 'gluten and antibodies' yielded 2529 hits.

IAlthough we discourage the use of the term 'CD serology', we have provided a definition for this term.

The purpose of our recommended definitions is to create a foundation for clinical management and research. Clear definitions will allow more efficient and generalisable advances in $\mathrm{CD}$ research relating to aetiology, incidence, prevalence, complications and treatment of patients with $\mathrm{CD}$ and other gluten-related disorders.

\section{METHODS}

\section{Task force constitution}

Members of this collaborative effort were invited to participate by two of the authors (DAL and CC). The constitution of the group reflects the wide variety of disciplines to which CD may present in practice: gastroenterology, histopathology, paediatrics, neurology and dermatology. Members of the task force were from Sweden, the USA, Argentina, Italy, the UK, Finland and Norway. Four of the five physicians from the USA had trained elsewhere (two in Ireland, one in Australia and one in Italy).

\section{Literature review}

Teams of three or four physicians were assigned between one and four CD-related terms. Each team carried out a literature search (table 1) of the entire electronic database PubMed up to January 2011 using the terms as key words. These terms included CD and the following descriptors of CD: asymptomatic, atypical, classical, latent, non-classical, overt, paediatric classical, potential, refractory, silent, subclinical, symptomatic, typical, CD serology, CD autoimmunity, genetically at risk of $\mathrm{CD}$, dermatitis herpetiformis, gluten, gluten ataxia, gluten intolerance, gluten sensitivity and gliadin-specific antibodies.

The literature review was mostly restricted to original papers and reviews. Most papers had been published after 1990. The teams then suggested definitions for each term.

\section{Web survey}

A web survey was then conducted and all suggested definitions were listed and subjected to peer review (online appendix).

Comments and feedback from the web survey were taken into account when creating a second set of definitions.

\section{Discussions and phone meetings}

The revised definitions and appending comments were then discussed in Oslo at the 14th International CD Symposium in June 2011. This discussion was followed by two phone conferences in which the remaining definitions were discussed until consensus was achieved. We did not grade the evidence underlying each definition because that was not the purpose of the task force and this review did not deal with clinical management. For the convenience of readers, each definition given in the Results section below is followed by a short literature review of each term. Two terms were added after the initial web survey and the meeting in Oslo: 'dermatitis herpetiformis' and 'CD autoimmunity', which were discussed through email.

\section{RESULTS}

\section{Coeliac disease}

Coeliac disease is a chronic small intestinal immune-mediated enteropathy precipitated by exposure to dietary gluten in genetically predisposed individuals.

$\mathrm{CD}$ is triggered by the ingestion of gluten (definition below), the protein component of wheat, rye, barley, but not oats. ${ }^{5} 6$ Such exposure results in a variable degree of intestinal damage. ${ }^{7}$ In most patients with $\mathrm{CD}$, the enteropathy will reverse on a GFD. ${ }^{2-4}$ According to the suggested definition, CD is a chronic disease, but as the discussion of the terms potential CD and latent $\mathrm{CD}$ will show, there are reports of transient $\mathrm{CD} .^{8}$

Although CD is the most common cause of enteropathy in the western world and enteropathy is a prerequisite for CD, it should be noted that other diseases may cause small intestinal inflammation but do not qualify as CD. ${ }^{9}$ Typically, the inflammation in CD includes an increased intraepithelial lymphocyte (IEL) count, most often $>25 / 100$ cells. ${ }^{9} 10$ Another feature of CD is that it incorporates an adaptive T-cell-mediated response (to gluten) and that it occurs in people who are DQ2-DQ8 positive. ${ }^{11} 12$ Increasingly, the presence of specific endomysial antibodies (EMA, also called AEA), anti-tissue transglutaminase antibodies (TTG, a-tTG, TTA), and/or deamidated antigliadin antibodies (DGP) plays an important role in the serological work-up for CD. These antibodies strongly support the diagnosis of $\mathrm{CD}$, but by themselves are not confirmatory.

To confirm a diagnosis of $\mathrm{CD}$, biopsies of the duodenum must be taken when patients are on a gluten-containing diet. Consensus states four to six biopsies are necessary for diagnosis, ${ }^{13}$ including from the duodenal bulb. ${ }^{14} 15$

Three histological classifications of CD are used: Marsh, ${ }^{7}$ Marsh-Oberhuber ${ }^{16}$ and Corazza. ${ }^{10} \mathrm{~A}$ comparison of these classifications is shown in table 2. 
Table 2 Comparison of histopathological classifications

\begin{tabular}{|c|c|c|c|}
\hline \multirow[b]{2}{*}{ Morphology of duodenal mucosal biopsy } & \multicolumn{3}{|l|}{ Classification } \\
\hline & $\overline{\text { Marsh* } 7}$ & Marsh-Oberhuber $^{16}$ & Corazza $^{10}$ \\
\hline Normal & Type 0 & Type 0 & Normal \\
\hline $\begin{array}{l}\text { Normal architecture and increased intraepithelial } \\
\text { lymphocytes } \geq 25 / 100 \text { enterocytes }\end{array}$ & Type 0 & Type 0 & Grade A \\
\hline $\begin{array}{l}\text { Normal architecture and increased intraepithelial } \\
\text { lymphocytes } \geq 40 / 100 \text { enterocytes }\end{array}$ & Type 1 & Type 1 & Grade A \\
\hline $\begin{array}{l}\text { Normal architecture and increased intraepithelial } \\
\text { lymphocytes } \geq 40 / 100 \text { enterocytes with crypt hyperplasia }\end{array}$ & Type 2 & Type 2 & Grade A \\
\hline \multirow[t]{3}{*}{$\begin{array}{l}\text { Partial villous atrophy and increased intraepithelial } \\
\text { lymphocytes } \geq 40 / \geq 25 / 100 \text { enterocytes }\end{array}$} & $\begin{array}{l}\text { Type } 2 \text { hyperplastic lesion } \\
\text { Crypt hyperplasia, increased } \\
\text { crypt height and influx of } \\
\text { inflammatory cells }\end{array}$ & Type 3 destructive & $\begin{array}{l}\text { Grade B1 atrophic, villous } \\
\text { to crypt ratio is }<3: 1\end{array}$ \\
\hline & & $\begin{array}{l}\text { Type 3a partial villous atrophy; } \\
\text { villi blunt and shortened with } \\
\text { a villous:crypt ratio, } 1: 1\end{array}$ & \\
\hline & & $\begin{array}{l}\text { Type } 3 \text { b subtotal villous atrophy; } \\
\text { villi atrophic but still separate } \\
\text { and recognisable }\end{array}$ & \\
\hline $\begin{array}{l}\text { Total villous atrophy intraepithelial lymphocytes } \\
\geq 40 / \geq 25 / 100 \text { enterocytes }\end{array}$ & $\begin{array}{l}\text { Type } 3 \text { destructive severe } \\
\text { inflammation, flat villi; } \\
\text { hyperplastic crypts }\end{array}$ & $\begin{array}{l}\text { Type } 3 c \text { total villous atrophy; } \\
\text { villi rudimentary or absent; mucosa } \\
\text { resembles colonic mucosa }\end{array}$ & $\begin{array}{l}\text { Grade B2 atrophic, villi are } \\
\text { no longer detectable }\end{array}$ \\
\hline $\begin{array}{l}\text { Atrophic hypoplastic lesion: flat mucosa, normal crypt } \\
\text { height, no inflammation with normal intraepithelial } \\
\text { lymphocyte counts }\end{array}$ & No equivalent & Type 4 & No equivalent \\
\hline
\end{tabular}

*Marsh initially explored the association of mucosal damage with a progressively increased gluten intake in treated patients with celiac disease. This staging has since been used as a classification.

Historically, CD has been equivalent to sprue, coeliac sprue, gluten-sensitive enteropathy and gluten intolerance. In the past the terms non-tropical sprue and idiopathic steatorrhoea were used. ${ }^{17} 18$ None of these terms are currently recommended.

\section{Gluten}

Gluten is the commonly used term for the complex of water insoluble proteins from wheat, rye and barley that are harmful to patients with CD.

The major seed proteins in cereals are the alcohol-soluble prolamins, a complex group of alcohol-soluble polypeptides that make up about half of the protein in the mature grain. The term gluten indicates a broad group of prolamins (gliadins and glutenins) found in wheat. Other prolamins showing similar immunogenic properties are also found in rye (secalins), barley (hordeins) and other closely related grains. ${ }^{13} 19$ The major prolamins of the more distantly related maize (zeins) seem to have evolved independently and show no harmful effects in patients with CD. Oats have also been shown to be non-immunogenic in most patients with $\mathrm{CD}^{20}{ }^{20} \mathrm{~A}$ GFD usually indicates a diet free from wheat, rye, barley, triticale, kamut and spelt.

Gluten is poorly digested in the human intestine with or without CD. Gluten peptides cross intact into the submucosa of the small intestine. In the submucosa of the small intestine the human enzyme transglutaminase 2 also referred to as tissue transglutaminase (tTG) deamidates gluten peptides, which allows for high-affinity binding to human leucocyte antigen (HLA) DQ2 and HLA DQ8 molecules, subsequently triggering an inflammatory reaction in patients with CD. ${ }^{12}$

Gluten content in food is regulated by the Codex Alimentarius (http://www.codexalimentarius.net). This codex (CODEX STAN 118-1979 revised in 2008) states that gluten-free foods are foods or ingredients naturally free of gluten, in which the measured gluten level is $\leq 20 \mathrm{mg} / \mathrm{kg}$ in total, or processed to $<100 \mathrm{mg} / \mathrm{kg}$. According to the current Codex, foods meeting these criteria may be labelled as a 'gluten-free food'.

\section{Asymptomatic CD}

Asymptomatic CD is not accompanied by symptoms even in response to direct questioning at initial diagnosis.

Individuals with asymptomatic CD do not manifest any symptoms commonly associated with $\mathrm{CD}$ and have no symptoms that respond to gluten withdrawal, even in response to direct questioning. These patients are often diagnosed through testing of populations enrolled in screening programmes or in case-finding strategies for detecting CD in patients with disorders that are associated with a high risk for CD. ${ }^{21-33}$ Many of these patients suffer from decreased quality of life. Sometimes minor symptoms (eg, fatigue) are only recognised after the introduction of a GFD; ${ }^{34}$ such patients do not suffer from true asymptomatic $\mathrm{CD}$ and should be reclassified as having subclinical CD.

\section{Typical CD}

Historically, typical CD has denoted a gluten-induced enteropathy presenting with signs or symptoms of malabsorption/ global malabsorption (such as diarrhoea or malnutrition) or a malabsorption syndrome (indicated by weight loss, steatorrhoea and oedema secondary to hypoalbuminemia). The above use is questionable in that the clinical presentation of $\mathrm{CD}$ has changed over time, ${ }^{35-37}$ and the word 'typical' implies that this form is the most frequently encountered form of CD. In contrast, many current patients have symptoms such as anaemia, $^{38-40}$ fatigue $^{41} 42$ and abdominal pain. ${ }^{43}$

We therefore discourage the use of the term typical CD.

\section{Atypical CD}

Atypical CD can only be used in reference to typical CD. Historically, atypical CD has been used to describe patients with gluten-induced enteropathy who have no weight loss but present with any of the following symptoms or signs: gastrointestinal symptoms, ${ }^{44}$ including symptoms suggestive of irritable bowel syndrome ${ }^{45}$ and liver dysfunction ${ }^{47} 48$; extraintestinal manifestations, such as metabolic disease/ 
symptoms (failure to thrive, thyroid dysfunction (hypo/ hyper) $)^{49} 50$; neurologic findings, ${ }^{51-53}$ including depression ${ }^{54}$ and gluten ataxia ${ }^{55}$; reproductive disease ${ }^{56-58}$ including abnormalities in menarche and menopause ${ }^{58}$ 59; oral/cutaneous disease, ${ }^{60-64}$ including dermatitis herpetiformis $(\mathrm{DH}){ }^{65}$ and skeletal findings. ${ }^{66}$ Atypical CD has also been used to denote patients with a gluten-induced enteropathy and significant nutritional deficiencies (such as iron deficiency). We argue that the term atypical CD should not be used. Some patients previously described as having atypical CD may fulfil the requirements for non-classical CD (see below).

\section{Classical CD}

Classical CD presents with signs and symptoms of malabsorption. Diarrhoea, steatorrhoea, weight loss or growth failure is required.

Classical and typical CD have traditionally been similar concepts defining the presence of a gluten-induced enteropathy presenting with diarrhoea, malnutrition or a malabsorption syndrome (indicated by weight loss, steatorrhoea and oedema secondary to hypoalbuminemia). ${ }^{76-74}$ While recognising that these symptoms are not specific to $\mathrm{CD}$, we encourage the use of classical CD, as defined above, because the term 'classical' does not imply that this type of $\mathrm{CD}$ is more common than $\mathrm{CD}$ without clinical malabsorption. Examples of classical CD are patients with diarrhoea and weight loss but also patients with weight loss and anaemia.

Paediatric classical CD is the paediatric equivalent of classical $\mathrm{CD}$. These children are often characterised by failure to thrive, diarrhoea, muscle wasting, poor appetite and abdominal distension. ${ }^{75-79}$ Many children with classical CD and malabsorption also show signs of emotional distress ("change of mood') and lethargy. ${ }^{72}$

\section{Non-classical CD}

Non-classical CD presents without signs and symptoms of malabsorption.

In non-classical CD the patient does not suffer from malabsorption (eg, a patient with constipation and abdominal pain but no malabsorption). Patients with monosymptomatic disease (other than diarrhoea or steatorrhoea) usually have non-classical CD.

\section{Silent CD}

Silent $\mathrm{CD}$ is equivalent to asymptomatic CD. We discourage the use of the term silent CD.

\section{Subclinical CD}

Subclinical CD is below the threshold of clinical detection.

The term subclinical has often been used to denote silent $\mathrm{CD}^{80-82}$ or patients with $\mathrm{CD}$ and extraintestinal symptoms (and no gastrointestinal symptoms). ${ }^{83}$ The term has also been used for patients with CD who have clinical or laboratory signs (iron deficiency anaemia, abnormalities in liver function tests, enamel defects, incidental endoscopic features, osteoporosis, etc) but no symptoms. ${ }^{84}$

As understanding of CD has advanced, new disease associations have been regularly found and populations tested for CD have changed in response. For this reason, what is 'subclinical' has changed over time. To provide a stable definition, we specified subclinical CD to be disease that is below the threshold of clinical detection without signs or symptoms sufficient to trigger $\mathrm{CD}$ testing in routine practice.

\section{Symptomatic CD}

Symptomatic CD is characterised by clinically evident gastrointestinal and/or extraintestinal symptoms attributable to gluten intake.

The clinical manifestations of CD vary from none (asymptomatic $\mathrm{CD}$ ) to a wide spectrum of symptoms. The vast majority of authors describing symptomatic CD do not distinguish between $\mathrm{CD}$ with gastrointestinal symptoms and $\mathrm{CD}$ with extraintestinal symptoms. ${ }^{85-98}$

What was previously called overt CD should be considered part of symptomatic CD.

\section{Overt CD}

Overt CD has most often been characterised by clinically evident gluten-related symptoms, either gastrointestinal (dyspepsia, diarrhoea and bloating) or extraintestinal (neurological symptoms and fatigue). ${ }^{99} 100$ We recommend that the term overt CD should not be used; symptomatic CD is the preferred term.

\section{Refractory CD}

Refractory CD (RCD) consists of persistent or recurrent malabsorptive symptoms and signs with villous atrophy (VA) despite a strict GFD for more than 12 months.

Although definitions of RCD differ slightly, ${ }^{101-118}$ most expert-opinion-based definitions include persistence or recurrence of malabsorptive symptoms and signs (eg, diarrhoea, abdominal pain, involuntary loss of weight, low haemoglobin and hypoalbuminemia) associated with persistent or recurrent VA despite a strict GFD for more than 12 months (or severe persistent symptoms independently of the duration of GFD) in the absence of other causes of VA or malignant complications ${ }^{119}$ and after the confirmation of the initial diagnosis of CD.

Generally, most patients are negative for EMA and TTG at the time of RCD diagnosis, but the presence of persisting elevated titres of circulating EMA and/or TTG does not necessarily rule out RCD, though this should lead to questions about dietary adherence. In all cases, a careful dietary interview should be performed to exclude gluten exposure before diagnosing RCD. ${ }^{120}$ Not all dietary non-responsive $\mathrm{CD}$ is RCD. ${ }^{121-123}$

RCD is divided into two categories ${ }^{111}{ }^{115}$ : type I, in which a normal IEL phenotype is found; and type II, in which there is a clonal expansion of an aberrant IEL population. The abnormal phenotype is supported by loss of normal surface markers CD3, CD4 and CD8 with preserved expression of intracytoplasmic CD3 (CD3 $\epsilon$ ) in $>50 \%$ of IELs as evaluated by immunohistochemistry or $>20 \%$ as determined by flow cytometry, and by detection of clonal rearrangement of T-cell receptor chains $(\gamma$ or

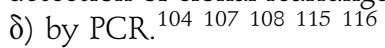

\section{Latent CD}

The literature reveals at least five definitions of latent CD: positive $\mathrm{CD}$ serology in patients with normal mucosa or absence of $\mathrm{VA} ;{ }^{124-129}$ and normal mucosa in patients who are on a gluten-containing diet, but have had an earlier or will have a later flat mucosa when they eat gluten. ${ }^{130-134}$ To some physicians latent $\mathrm{CD}$ is simply equivalent to undiagnosed $\mathrm{CD},{ }^{135} 136$ whereas others refer to latent CD as CD preceded by another autoimmune disease (eg, type I diabetes or thyroid disease). Finally, latent CD is sometimes used to denote normal mucosa with non-serological abnormalities, such as an increased number of $\gamma$ or $\delta$ cells, or increased mucosal permeability. ${ }^{137}$ Considering that the terms potential $\mathrm{CD}$ and latent $\mathrm{CD}$ have 
often been used interchangeably, resulting in confusion, we discourage the use of the term latent CD.

\section{Potential CD}

Potential CD relates to people with a normal small intestinal mucosa who are at increased risk of developing $\mathrm{CD}$ as indicated by positive $\mathrm{CD}$ serology.

Potential CD is also often used with different meanings. For some, potential $\mathrm{CD}$ means that the patient has an increased number of IELs in the villi ${ }^{138}$ or increased expression of $\gamma$ or $\delta$ cells. ${ }^{139}$ To others, potential CD describes people with normal mucosa but positive CD serology. ${ }^{140}{ }^{141}$ Adding to this is the suggestion by Ferguson et al that all first-degree relatives to patients with CD have potential CD. ${ }^{142}$

We recommend that the term potential CD be used for people with normal small intestinal mucosa who are at increased risk of developing $\mathrm{CD}$ as indicated by positive CD serology. A difficulty in the definition of this group is variability in the adequacy of the biopsies that were taken to exclude the diagnosis of active $\mathrm{CD}$, especially with the current knowledge that at least four biopsies need to be taken ${ }^{143}$ and the bulb may be the only location of VA. ${ }^{15}$

\section{CD autoimmunity}

CD autoimmunity relates to increased TTG or EMA on at least two occasions when status of the biopsy is not known. If the biopsy is positive, then this is $\mathrm{CD}$, if the biopsy is negative than this is potential CD.

The term 'coeliac disease autoimmunity' or 'coeliac autoimmunity' has been used to describe: individuals with positive TTG, ${ }^{144-147}$ positive EMA, ${ }^{148}$ positive EMA with positive/ borderline TTG, ${ }^{149}$ positive TTG on at least two occasions, ${ }^{150}$ and positive TTG on two occasions or a positive small bowel biopsy after only a single positive TTG. ${ }^{151}$

We defined CD autoimmunity as positive TTG or EMA on at least two occasions. In a clinical setting this will lead to a small intestinal biopsy, and patients can then be classified as either CD (positive biopsy) or potential CD (negative biopsy), but in a research setting there are circumstances when small intestinal biopsy has not been performed. The term CD autoimmunity should then be used. When TTG or EMA has only been tested on one occasion, it is preferable to refer to patients as TTG positive or EMA positive.

\section{Genetically at risk of CD}

Family members of patients with CD that test positive for HLA DQ2 and/or DQ8 are genetically at risk of CD.

$\mathrm{CD}$ is a multifactorial condition with unparallelled evidence of the pivotal role of HLA-DOA1*05-DOB1*02 (DQ2) and DOA $1 * 03-\mathrm{DOB} 1 * 0302$ (DO8) in disease predisposition. ${ }^{152} 153$ DQ2 and DQ8 are major risk factors carried by almost all patients with CD. Interestingly, when carried in trans on DR5/ DR7 (ie, DQA1*05-DQB1*0301/DQA1*0201-DQB1*02) or DR3/ DR7 (ie, $D Q A 1 * 05-D Q B 1 * 02 / D Q A 1 * 0201-D Q B 11^{*} 02$ ) genotypes, the risk of $\mathrm{CD}$ in southern Europeans is higher than when the alleles are carried in cis on DR3 (ie, $D Q A 1^{*} 05-D Q B 1^{*} 02$ ) alone, suggesting that additional factors in the region may be influencing disease propensity.

Non-HLA genes together contribute more to genetic susceptibility (approximately 65\%) than the HLA genes (the remaining $35 \%$ ), but the contribution from each single, predisposing nonHLA gene appears to be modest. ${ }^{154}$

At the moment, the concept of genetically at risk for CD should be limited to family members (of patients with CD) who test positive for HLA-DQ2 or HLA-DQ8, with the understanding that the risk varies between $2 \%$ and $20 \%$, depending on the degree of the relative with CD and the number of copies of HLA-DQ2 genes. However, people who harbour these genes are at risk of developing $\mathrm{CD}$.

\section{Gluten intolerance}

The term gluten intolerance has been used as a synonym of $\mathrm{CD}$ and to indicate that a patient experiences a clinical improvement after starting a GFD, even when they do not have CD. ${ }^{8} 76122{ }^{155-166}$ However, we believe the term gluten intolerance is non-specific and carries inherent weaknesses and contradictions. Although gluten intolerance could be a consequence of poor digestion, it could also be the effect of some lectin-like properties of gluten or foods generated from gluten that cause gastrointestinal upset. Another problem is that gluten intolerance may not truly reflect intolerance to gluten but to other wheat components. ${ }^{156}$ Because of these contradictions, we recommend that the term gluten intolerance should not be used and that gluten-related disorders be used instead.

\section{Gluten-related disorders}

Gluten-related disorders is a term used to describe all conditions related to gluten.

We recommend that this term is used to describe all conditions related to gluten. This may include disorders such as gluten ataxia, DH, non-coeliac gluten sensitivity (NCGS) and CD. ${ }^{115} 167168$

\section{Gluten sensitivity}

In some papers the term gluten sensitivity is used synonymously with $\mathrm{CD}^{7}$ Other papers used the concept of gluten sensitivity as an umbrella term to include CD and other conditions related to gluten ingestion, such as $\mathrm{DH}^{169}$ gluten ataxia ${ }^{170}$ and NCGS. ${ }^{156}$ Most recently, ${ }^{157}{ }^{171-174}$ several authors employed the term gluten sensitivity to describe a condition in which symptoms are triggered by gluten ingestion, in the absence of TTG or EMA antibodies and enteropathy, with variable HLA status and variable anti-gliadin (AGA) presence. It is important to distinguish CD from less well characterised diseases related to gluten ingestion. We therefore recommend that the term gluten sensitivity should not be used and that NCGS be used instead.

\section{Non-coeliac gluten sensitivity}

The term NCGS relates to one or more of a variety of immunological, morphological or symptomatic manifestations that are precipitated by the ingestion of gluten in people in whom $\mathrm{CD}$ has been excluded.

NCGS is a condition in which gluten ingestion leads to morphological or symptomatic manifestations despite the absence of CD. ${ }^{172-176}$ As opposed to CD, NCGS may show signs of an activated innate immune response but without the enteropathy, elevations in tTG, EMA or DGP antibodies, and increased mucosal permeability characteristic of CD. ${ }^{173}$ Recently, in a double-blind randomised trial, Biesiekierski et al showed that patients with NCGS truly develop symptoms when eating gluten. ${ }^{156}$ It is unclear at this time what components of grains trigger symptoms in people with NCGS and whether some populations of patients with NCGS have subtle small intestinal morphological changes. While there is currently no standard diagnostic approach to NCGS, systematic evaluation should be conducted, including exclusion of CD and other inflammatory disorders. 


\section{Gliadin-specific antibodies}

These are AGAs of IgA and IgG subclass recognising the gliadin moiety of wheat. Antibodies recognising native gluten are now rarely used for diagnostic purposes because they lack general specificity. Antibodies recognising DGP demonstrate high specificity and sensitivity. They can also be used for measurement of gluten in foodstuffs.

Use of the term gliadin-specific antibodies generally refers to antibodies directed against the gliadin moiety of wheat prolamins. The following four aspects of these antibodies are relevant to the spectrum of gluten-induced disease.

\section{Diagnostic value}

After introduction in the 1980s, IgA antibodies against wheat gliadin (AGAs) served as the best serological test for $\mathrm{CD}$ for some years. ${ }^{177} 178$ However, the low positive predictive value ${ }^{179}$ meant that this test has since been abandoned for the investigation of $\mathrm{CD},{ }^{13}{ }^{179}$ except for in children younger than 18 months, in whom IgA AGA seems to have high sensitivity. ${ }^{180}$ Recently, assays for IgA and IgG antibodies against DGP have been introduced $^{181}$ and perform similarly to TTG-based tests. ${ }^{179}$

\section{Increased gut permeability}

Elevated levels of AGAs have also been used for the investigation of possible increased gut permeability, but this use in clinical practice lacks a strong scientific background.

\section{Disorders beyond the classical enteropathy}

AGAs are also relevant to gluten-induced disorders beyond the classical enteropathy. The most well known example is gluten ataxia. Patients with this disorder may have CD or only elevated levels of IgA or IgG AGAs ${ }^{55}$ (see gluten ataxia).

\section{Measurement of gluten in foods}

Gluten-specific antibodies have a clear role in the food industry in that they are indispensable for measurement of gluten in foods. More recently, an assay using a monoclonal antibody recognising a major coeliac toxic epitope has been developed. ${ }^{182}$ This assay is now the preferred method for gluten analysis in food. ${ }^{183}$

\section{Coeliac disease serology}

Coeliac disease serology is a term that includes endomysium, transglutaminase, deamidated gliadin antibodies, and in small children also gliadin antibodies for the assessment of CD.

Since the introduction of AGAs, antibodies have become an important means to diagnose CD. Serological testing has been used routinely in the investigation of CD since the 1980s. Whereas AGA tests were common in the 1980s and 1990s, ${ }^{184}$ laboratories have since gradually shifted to EMA and TTG tests. ${ }^{185-187}$ In most patient groups with suspected CD, EMA and TTG tests have a higher sensitivity and specificity than the AGA test. ${ }^{188}$ We defined CD serology as an all-encompassing term that includes all available tests which have been shown in clinical studies to be sensitive for assessment of CD. Accordingly, we discourage the use of the term CD serology in that it is preferable to specify the antibody tests used because sensitivity and specificity differ substantially. We have nevertheless suggested a definition of this term because it is extensively used.

\section{Gluten ataxia}

Gluten ataxia can be defined as idiopathic sporadic ataxia and positive serum antigliadin antibodies even in the absence of duodenal enteropathy.
Gluten ataxia is one of a number of neurological manifestations attributed to CD. Defining criteria for gluten ataxia ${ }^{170} 189190$ include otherwise idiopathic sporadic ataxia in association with positive AGA with or without enteropathy on duodenal biopsy. Most reports (22 of 35 reports) after 1998 have used the same definition, that is, idiopathic sporadic ataxia with positive AGA (IgG or IgA, or both). However, a number of reports refer to patients with established $\mathrm{CD}$ (13 of 35 reports) without always providing serological information on these patients other than stating that the patient had CD (taken to imply the presence of enteropathy). ${ }^{170} 191-199$

One report examined the presence of IgA deposits on duodenal biopsies and found that all 10 patients with gluten ataxia (without enteropathy) had such deposits. ${ }^{195}$ One study has identified a novel transglutaminase (TTG6) as a potential new serological marker for gluten ataxia, ${ }^{192}$ but currently the most appropriate definition for gluten ataxia remains that of idiopathic sporadic ataxia with positive AGA.

\section{Dermatitis herpetiformis}

$\mathrm{DH}$ is a cutaneous manifestation of small intestinal immunemediated enteropathy precipitated by exposure to dietary gluten. It is characterised by herpetiform clusters of pruritic urticated papules and vesicles on the skin, especially on the elbows, buttocks and knees, and IgA deposits in the dermal papillae. DH responds to a GFD.

$\mathrm{DH}$ is characterised by the presence of $\operatorname{IgA}$ deposits in the skin, ${ }^{200-202}$ is strongly linked to an immune-mediated enteropathy precipitated by gluten, ${ }^{65} 203-205$ and responds to a GFD. ${ }^{206-209}$ A study from the USA in 1992 documented a prevalence of 11.2 per 100000 people and an incidence of 0.98 per 100000 people per year. ${ }^{210}$ These rates are comparable to earlier studies of prevalence of DH in northern Europe. ${ }^{205}$

VA will be revealed by a single intestinal biopsy in two-thirds of patients, and by multiple biopsies in $95 \%$. The enteropathy is variable in severity, but even in the presence of normal villous architecture, elevated levels of $\gamma \delta \mathrm{T}$ lymphocytes in the intestinal mucosa, elevated IEL counts and induction of VA are noted on gluten challenge, and these patients are very likely to reflect the entire spectrum of histological and clinical $C D$ in adults. ${ }^{65} 211$ The association with HLA is the same as in CD: $90 \%$ of patients have HLA DQ2 and almost all the remainder have HLA DQ8. ${ }^{212}$ The skin lesions clear with gluten withdrawal but may also require treatment by the neutrophil inhibitor dapsone. ${ }^{207} 208213$ In the long term, adherence to a strict GFD shows $47 \%$ of patients can stop drug treatment completely; however $15 \%$ will not be able to reduce the dose of dapsone. $^{214}$

\section{DISCUSSION}

This review was based on PubMed literature searches and expert meetings. We aimed to define key concepts relevant to $\mathrm{CD}$ and related disorders. The character of the current paper implies that we did not pool any data or use any statistical tools. Instead, we assembled an international team of recognised experts in CD research, discussed definitions and tried to reach a consensus. This approach is similar to that of previous papers on definitions of CD. ${ }^{2-4}$ As opposed to previous studies, ${ }^{2-4}$ however, we did not limit ourselves to 'CD only' but defined a large number of concepts. In addition, we provide guidance to the scientific and clinical community as to which terms should be used and which should be abandoned.

Overall, we evaluated more than 300 papers in detail and all authors participated in the discussion leading to consensus 
definitions. We tried to avoid cumbersome definitions and have mostly avoided the inclusion of specific techniques, antibodies and measurements or units in these definitions. Cumbersome definitions are rarely used in practice and because of the progress in the $\mathrm{CD}$ research field, statements on specific tests may rapidly become obsolete.

Our research team was multidisciplinary and was composed of specialists from gastroenterology, pathology, paediatrics, neurology and dermatology. We hope that our definitions will be acceptable to all specialties dealing with CD and gluten-related disorders and anticipate that they will facilitate both research and clinical management of patients with these disorders.

\section{Author affiliations}

${ }^{1}$ Department of Paediatrics, Örebro University Hospital, Örebro, Sweden

${ }^{2}$ Clinical Epidemiology Unit, Department of Medicine, Karolinska Institutet, Stockholm, Sweden

${ }^{3}$ Division of Gastroenterology, Beth Israel Deaconess Medical Center, Harvard Medical School, Boston, Massachusetts, USA

${ }^{4}$ Department of Medicine, Dr C. Bonorino Udaondo Gastroenterology Hospital, Del Salvador University, Buenos Aires, Argentina

${ }^{5}$ Coeliac Centre/First Department of Internal Medicine, University of Pavia, Pavia, Italy ${ }^{6}$ Center for Coeliac Research, University of Maryland School of Medicine, Baltimore, Maryland, USA

${ }^{7}$ Coeliac Disease Center, Columbia University, New York, New York, USA

${ }^{8}$ Department of Neurology, Royal Hallamshire Hospital, Sheffield, UK

${ }^{9}$ School of Medicine, FIN-33014 University of Tampere, Tampere, Finland

${ }^{10}$ Department of Dermatology, Imperial College NHS Healthcare Trust, St Mary's

Hospital, London, UK

${ }^{11}$ Department of Gastroenterology and Centre for Immune Regulation, Oslo University Hospital, Oslo, Norway

${ }^{12}$ Department of Gastroenterology and Hepatology, Mayo Clinic, Rochester, Minnesota, USA

${ }^{13}$ Gastroenterology and Liver Unit, Royal Hallamshire Hospital, Unversity of Sheffield, Sheffield, UK

${ }^{14}$ Centre for Pathology, Faculty of Medicine, Imperial College, St Mary's Hospital, London, UK

${ }^{15}$ Department of Clinical and Experimental Medicine, Federico II University of Naples, Naples, Italy

${ }^{16}$ Department of Gastroenterology, University of Salerno, Salerno, Italy

Contributors CC and DAL initiated the study. JFL coordinated the project, conducted the web survey on coeliac disease definitions, and wrote the first draft of the paper. All authors contributed to the literature searches, contributed to the writing of the article, and approved the final version of the article.

Funding JFL was supported by the Swedish Research Council (522-2A09-195) and the Swedish Society of Medicine while writing the draft of this paper. DAL is supported by the National Institute of Health (NIH DK1042103881). None of the funding organisations had any role in the design and conduct of the study; collection, management, analysis and interpretation of the data; and preparation, review, or approval of the article.

Competing interests None.

Provenance and peer review Not commissioned; externally peer reviewed.

Data sharing statement All data are available on request.

\section{REFERENCES}

1. van Berge-Henegouwen GP, Mulder CJ. Pioneer in the gluten free diet Willem-Karel Dicke 1905-1962, over 50 years of gluten free diet. Gut 1993;34:1473-5.

2. Meeuwisse GW. Round table discussion. Diagnostic criteria in coeliac disease. Acta Paediatr 1970:59:461-3.

3. McNeish AS, Harms HK, Rey J, et al. The diagnosis of coeliac disease. A commentary on the current practices of members of the European Society for Paediatric Gastroenterology and Nutrition (ESPGAN). Arch Dis Child 1979;54:783-6.

4. Anon. Revised criteria for diagnosis of coeliac disease. Report of Working Group of European Society of Paediatric Gastroenterology and Nutrition. Arch Dis Child 1990;65:909-11.

5. Janatuinen EK, Pikkarainen $\mathrm{PH}$, Kemppainen TA, et al. A comparison of diets with and without oats in adults with celiac disease. $N$ Engl J Med 1995;333:1033-7.

6. Vader LW, de Ru A, van der Wal Y, et al. Specificity of tissue transglutaminase explains cereal toxicity in celiac disease. J Exp Med 2002;195:643-9.
7. Marsh MN. Gluten, major histocompatibility complex, and the small intestine. A molecular and immunobiologic approach to the spectrum of gluten sensitivity ('celiac sprue'). Gastroenterology 1992;102:330-54.

8. Walker-Smith JA. Transient gluten intolerance. Arch Dis Child 1996;74:183-4

9. Walker MM, Murray JA, Ronkainen J, et al. Detection of celiac disease and lymphocytic enteropathy by parallel serology and histopathology in a populationbased study. Gastroenterology 2010;139:112-19.

10. Corazza GR, Villanacci V, Zambelli C, et al. Comparison of the interobserver reproducibility with different histologic criteria used in celiac disease. Clin Gastroenterol Hepatol 2007;5:838-43

11. Lundin KE, Scott H, Hansen T, et al. Gliadin-specific, HLA-DQ(alpha $1^{*} 0501$, beta $\left.1{ }^{*} 0201\right)$ restricted $T$ cells isolated from the small intestinal mucosa of celiac disease patients. J Exp Med 1993;178:187-96.

12. Molberg 0, McAdam SN, Korner R, et al. Tissue transglutaminase selectively modifies gliadin peptides that are recognized by gut-derived T cells in celiac disease. Nat Med 1998;4:713-17. [published erratum appears in Nat Med 1998;4:974].

13. Rostom A, Murray JA, Kagnoff MF. American Gastroenterological Association (AGA) Institute technical review on the diagnosis and management of celiac disease. Gastroenterology 2006;131:1981-2002.

14. Hopper AD, Cross SS, Sanders DS. Patchy villous atrophy in adult patients with suspected gluten-sensitive enteropathy: is a multiple duodenal biopsy strategy appropriate? Endoscopy 2008;40:219-24.

15. Gonzalez S, Gupta A, Cheng J, et al. Prospective study of the role of duodenal bulb biopsies in the diagnosis of celiac disease. Gastrointest Endosc 2010;72:758-65.

16. Oberhuber G, Granditsch G, Vogelsang H. The histopathology of coeliac disease: time for a standardized report scheme for pathologists. Eur J Gastroenterol Hepatol 1999;11:1185-94

17. AGA Institute. AGA Institute medical position statement on the diagnosis and management of celiac disease. Gastroenterology 2006;131:1977-80.

18. Crowe SE. In the clinic. Celiac disease. Ann Intern Med 2011;154:ITC5-1-15; quiz ITC5-16.

19. Platt SG, Kasarda DD. Separation and characterization of -gliadin fractions. Biochim Biophys Acta 1971;243:407-15.

20. Koskinen 0, Villanen M, Korponay-Szabo I, et al. Oats do not induce systemic or mucosal autoantibody response in children with coeliac disease. J Pediatr Gastroenterol Nutr 2009:48:559-65.

21. Katz KD, Rashtak S, Lahr BD, et al. Screening for celiac disease in a North American population: sequential serology and gastrointestinal symptoms. Am J Gastroenterol 2011:106:1333-9.

22. Tursi A, Elisei W, Giorgetti GM, et al. Prevalence of celiac disease and symptoms in relatives of patients with celiac disease. Eur Rev Med Pharmacol Sci 2010;14:567-72.

23. Freeman HJ. Risk factors in familial forms of celiac disease. World J Gastroenterol 2010;16:1828-31.

24. Legroux-Gerot I, Leloire 0, Blanckaert $F$, et al. Screening for celiac disease in patients with osteoporosis. Joint Bone Spine 2009;76:162-5.

25. Barker JM, Liu E. Celiac disease: pathophysiology, clinical manifestations, and associated autoimmune conditions. Adv Pediatr 2008;55:349-65.

26. Alzahrani AS, Al Sheef M. Severe primary hyperparathyroidism masked by asymptomatic celiac disease. Endocr Pract 2008;14:347-50.

27. Ch'ng CL, Jones MK, Kingham JG. Celiac disease and autoimmune thyroid disease. Clin Med Res 2007;5:184-92

28. Swigonski NL, Kuhlenschmidt HL, Bull MJ, et al. Screening for celiac disease in asymptomatic children with Down syndrome: cost-effectiveness of preventing lymphoma. Pediatrics 2006;118:594-602.

29. Dube C, Rostom A, Sy R, et al. The prevalence of celiac disease in average-risk and at-risk Western European populations: a systematic review. Gastroenterology 2005:128(4 Suppl 1):S57-67.

30. Kumar V, Rajadhyaksha M, Wortsman J. Celiac disease-associated autoimmune endocrinopathies. Clin Diagn Lab Immunol 2001;8:678-85.

31. Hoffenberg EJ, Bao F, Eisenbarth GS, et al. Transglutaminase antibodies in children with a genetic risk for celiac disease. J Pediatr 2000;137:356-60.

32. Lorini R, Scaramuzza A, Vitali L, et al. Clinical aspects of coeliac disease in children with insulin-dependent diabetes mellitus. J Pediatr Endocrinol Metab 1996:9 (Suppl 1):101-11.

33. Stewart J. Asymptomatic coeliac disease in adults. Ir Med J 1974;67:415-16

34. Marine M, Fernandez-Banares F, Alsina M, et al. Impact of mass screening for gluten-sensitive enteropathy in working population. World J Gastroenterol 2009:15:1331-8.

35. Maki M, Kallonen K, Lahdeaho ML, et al. Changing pattern of childhood coeliac disease in Finland. Acta Paediatr Scand 1988;77:408-12.

36. Ludvigsson JF, Ansved P, Falth-Magnusson K, et al. Symptoms and signs have changed in Swedish children with coeliac disease. J Pediatr Gastroenterol Nutr 2004;38:181-6.

37. Rampertab SD, Pooran N, Brar $\mathrm{P}$, et al. Trends in the presentation of celiac disease. Am J Med 2006;119:355.e9-14.

38. Corazza GR, Valentini RA, Andreani ML, et al. Subclinical coeliac disease is a frequent cause of iron-deficiency anaemia. Scand J Gastroenterol 1995:30:153-6.

39. Hin H, Bird G, Fisher $P$, et al. Coeliac disease in primary care: case finding study. BMJ 1999:318:164-7.

40. Unsworth DJ, Lock RJ, Harvey RF. Improving the diagnosis of coeliac disease in anaemic women. Br J Haematol 2000;111:898-901. 
41. Siniscalchi $\mathbf{M}$, lovino $\mathrm{P}$, Tortora $\mathrm{R}$, et al. Fatigue in adult coeliac disease. Aliment Pharmacol Ther 2005;22:489-94.

42. Sanders DS, Evans KE, Hadjivassiliou M. Fatigue in primary care. Test for coeliac disease first? BMJ 2010;341:c5161.

43. van der Windt DA, Jellema P, Mulder CJ, et al. Diagnostic testing for celiac disease among patients with abdominal symptoms: a systematic review. JAMA 2010;303:1738-46

44. Nachman F, Vazquez H, Gonzalez A, et al. Gastroesophageal reflux symptoms in patients with celiac disease and the effects of a gluten-free diet. Clin Gastroenterol Hepatol 2011;9:214-19.

45. Sanders DS, Carter MJ, Hurlstone DP, et al. Association of adult coeliac disease with irritable bowel syndrome: a case-control study in patients fulfilling ROME II criteria referred to secondary care. Lancet 2001;358:1504-8.

46. Ford AC, Chey WD, Talley NJ, et al. Yield of diagnostic tests for celiac disease in individuals with symptoms suggestive of irritable bowel syndrome: systematic review and meta-analysis. Arch Intern Med 2009;169:651-8.

47. Volta U, De Franceschi L, Lari F, et al. Coeliac disease hidden by cryptogenic hypertransaminasaemia. Lancet 1998;352:26-9.

48. Franzese A, lannucci MP, Valerio G, et al. Atypical celiac disease presenting as obesity-related liver dysfunction. J Pediatr Gastroenterol Nutr 2001:33:329-32.

49. Puri AS, Garg S, Monga R, et al. Spectrum of atypical celiac disease in North Indian children. Indian Pediatr 2004;41:822-7.

50. Elfstrom P, Montgomery SM, Kampe 0, et al. Risk of thyroid disease in individuals with celiac disease. J Clin Endocrinol Metab 2008;93:3915-21.

51. Lionetti E, Francavilla R, Pavone P, et al. The neurology of coeliac disease in childhood: what is the evidence? A systematic review and meta-analysis. Dev Med Child Neurol 2010;52:700-7.

52. Hadjivassiliou M, Grunewald RA, Kandler RH, et al. Neuropathy associated with gluten sensitivity. J Neurol Neurosurg Psychiatry 2006;77:1262-6.

53. Ludvigsson JF, Olsson T, Ekbom A, et al. A population-based study of coeliac disease, neurodegenerative and neuroinflammatory diseases. Aliment Pharmacol Ther 2007;25:1317-27

54. Ciacci C, lavarone A, Mazzacca G, et al. Depressive symptoms in adult coeliac disease. Scand J Gastroenterol 1998;33:247-50.

55. Hadjivassiliou M, Sanders DS, Woodroofe N, et al. Gluten ataxia. Cerebellum 2008;7:494-8.

56. Zugna D, Richiardi L, Akre 0, et al. A nationwide population-based study to determine whether coeliac disease is associated with infertility. Gut 2010:59:1471-5.

57. Ciacci C, Cirillo M, Auriemma G, et al. Celiac disease and pregnancy outcome. Am J Gastroenterol 1996;91:718-22.

58. Santonicola A, lovino P, Cappello C, et al. From menarche to menopause: the fertile life span of celiac women. Menopause 2011;18:1125-30.

59. Martinelli D, Fortunato F, Tafuri S, et al. Reproductive life disorders in Italian celiac women. A case-control study. BMC Gastroenterol 2010:10:89.

60. Corazza GR, Andreani ML, Venturo N, et al. Celiac disease and alopecia areata: report of a new association. Gastroenterology 1995;109:1333-7.

61. Ferguson MM, Wray D, Carmichael HA, et al. Coeliac disease associated with recurrent aphthae. Gut 1980;21:223-6.

62. Cheng J, Malahias T, Brar P, et al. The association between celiac disease, dental enamel defects, and aphthous ulcers in a United States cohort. J Clin Gastroenterol 2010; $44: 191-4$

63. Ludvigsson JF, Lindelof B, Zingone $F$, et al. Psoriasis in a nationwide cohort study of patients with celiac disease. J Invest Dermatol 2011;131:2010-16.

64. Pastore L, Lo Muzio L, Serpico R. Atrophic glossitis leading to the diagnosis of celiac disease. N Engl J Med 2007;356:2547.

65. Zone JJ. Skin manifestations of celiac disease. Gastroenterology 2005;128 (4 Suppl 1):S87-91.

66. Collin P, Korpela M, Hallstrom 0, et al. Rheumatic complaints as a presenting symptom in patients with coeliac disease. Scand J Rheumatol 1992;21:20-3.

67. Logan RF, Tucker G, Rifkind EA, et al. Changes in clinical features of coeliac disease in adults in Edinburgh and the Lothians 1960-79. Br Med J (Clin Res Ed) 1983;286:95-7.

68. Farrell RJ, Kelly CP. Diagnosis of celiac sprue. Am J Gastroenterol 2001;96:3237-46.

69. Wahab PJ, Meijer JW, Goerres MS, et al. Coeliac disease: changing views on gluten-sensitive enteropathy. Scand J Gastroenterol Supp/ 2002;236:60-5.

70. Lo W, Sano K, Lebwohl B, et al. Changing presentation of adult celiac disease. Dig Dis Sci 2003;48:395-8.

71. Mulder CJ, Cellier C. Coeliac disease: changing views. Best Pract Res Clin Gastroenterol 2005;19:313-21

72. Dewar DH, Ciclitira PJ. Clinical features and diagnosis of celiac disease. Gastroenterology 2005;128(4 Suppl 1):S19-24

73. Fasano A, Catassi C. Coeliac disease in children. Best Pract Res Clin Gastroenterol 2005:19:467-78.

74. Nachman F, Maurino E, Vazquez $\mathrm{H}$, et al. Quality of life in celiac disease patients: prospective analysis on the importance of clinical severity at diagnosis and the impact of treatment. Dig Liver Dis 2009;41:15-25.

75. Ascher H, Holm K, Kristiansson B, et al. Different features of coeliac disease in two neighbouring countries. Arch Dis Child 1993;69:375-80.

76. Bardella MT, Fredella C, Saladino V, et al. Gluten intolerance: gender- and age-related differences in symptoms. Scand J Gastroenterol 2005;40:15-19.
77. McGowan KE, Castiglione DA, Butzner JD. The changing face of childhood celiac disease in North America: impact of serological testing. Pediatrics 2009;124:1572-8

78. Visakorpi JK, Maki M. Changing clinical features of coeliac disease. Acta Paediatr Supp/ 1994;83:10-13

79. Fasano A. Clinical presentation of celiac disease in the pediatric population. Gastroenterology 2005;128(4 Suppl 1):S68-73

80. Meloni G, Dore A, Fanciulli G, et al. Subclinical coeliac disease in schoolchildren from northern Sardinia. Lancet 1999;353:37.

81. Corazza GR, Frisoni M, Treggiari EA, et al. Subclinical celiac sprue. Increasing occurrence and clues to its diagnosis. J Clin Gastroenterol 1993;16:16-21.

82. Bottaro G, Cataldo F, Rotolo N, et al. The clinical pattern of subclinical/silent celiac disease: an analysis on 1026 consecutive cases. Am J Gastroenterol 1999:94:691-6.

83. Moreno ML, Vazquez $\mathrm{H}$, Mazure $\mathrm{R}$, et al. Stratification of bone fracture risk in patients with celiac disease. Clin Gastroenterol Hepatol 2004;2:127-34.

84. Baccini F, Spiriti MA, Vannella L, et al. Unawareness of gastrointestina symptomatology in adult coeliac patients with unexplained iron-deficiency anaemia presentation. Aliment Pharmacol Ther 2006;23:915-21.

85. Koskinen 0, Collin P. Korponay-Szabo I, et al. Gluten-dependent small bowe mucosal transglutaminase 2-specific IgA deposits in overt and mild enteropathy coeliac disease. J Pediatr Gastroenterol Nutr 2008;47:436-42.

86. Tjon JM, van Bergen J, Koning F. Celiac disease: how complicated can it get? Immunogenetics 2010;62:641-51.

87. Ciacci C, Maiuri L, Russo I, et al. Efficacy of budesonide therapy in the early phase of treatment of adult coeliac disease patients with malabsorption: an in vivo/in vitro pilot study. Clin Exp Pharmacol Physiol 2009;36:1170-6.

88. West J, Logan RF, Hill PG, et al. The iceberg of celiac disease: what is below the waterline? Clin Gastroenterol Hepatol 2007;5:59-62.

89. Schuppan D, Kelly CP, Krauss N. Monitoring non-responsive patients with celiac disease. Gastrointest Endosc Clin N Am 2006;16:593-603.

90. Holtmeier W, Caspary WF. Celiac disease. Orphanet J Rare Dis 2006;1:3.

91. Lahdeaho ML, Kaukinen K, Collin P, et al. Celiac disease: from inflammation to atrophy: a long-term follow-up study. J Pediatr Gastroenterol Nutr 2005:41:44-8.

92. Karnam US, Felder LR, Raskin JB. Prevalence of occult celiac disease in patients with iron-deficiency anemia: a prospective study. South Med J 2004;97:30-4.

93. Barera G, Bonfanti R, Viscardi M, et al. Occurrence of celiac disease after onset of type 1 diabetes: a 6 -year prospective longitudinal study. Pediatrics 2002;109:833-8.

94. Volta U, Bellentani S, Bianchi FB, et al. High prevalence of celiac disease in Italian general population. Dig Dis Sci 2001;46:1500-5.

95. Ciacci C, Cirillo M, Giorgetti G, et al. Low plasma cholesterol: a correlate of nondiagnosed celiac disease in adults with hypochromic anemia. $\mathrm{Am} \mathrm{J}$ Gastroenterol 1999;94:1888-91.

96. Falth-Magnusson K, Franzen L, Jansson G, et al. Infant feeding history shows distinct differences between Swedish celiac and reference children. Pediatr Allergy Immunol 1996:7:1-5.

97. Doherty M, Barry RE. Gluten-induced mucosal changes in subjects without overt small-bowel disease. Lancet 1981;1:517-20.

98. Ciacci C, Cirillo M, Mellone M, et al. Hypocalciuria in overt and subclinical celiac disease. Am J Gastroenterol 1995;90:1480-4.

99. Polanco I, Mearin ML, Larrauri J, et al. Effect of gluten supplementation in healthy siblings of children with celiac disease. Gastroenterology 1987:92:678-81.

100. Caputo $\mathbf{M}$, Brizzolara R, Schiavo M, et al. Occurrence of overt celiac disease in the elderly following total thyroidectomy. J Endocrinol Invest 2006;29:831-3.

101. Roshan B, Leffler DA, Jamma S, et al. The incidence and clinical spectrum of refractory celiac disease in a North American referral center. Am J Gastroenterol 2011;106:923-8

102. van de Water JM, Cillessen SA, Visser OJ, et al. Enteropathy associated T-cell lymphoma and its precursor lesions. Best Pract Res Clin Gastroenterol 2010;24:43-56.

103. Walker MM, Murray JA. An update in the diagnosis of coeliac disease. Histopathology 2011:59:166-79.

104. Rubio-Tapia A, Murray JA. Classification and management of refractory coeliac disease. Gut 2010;59:547-57.

105. Ho-Yen C, Chang F, van der Walt J, et al. Recent advances in refractory coeliac disease: a review. Histopathology 2009:54:783-95.

106. Rubio-Tapia A, Kelly DG, Lahr BD, et al. Clinical staging and survival in refractory celiac disease: a single center experience. Gastroenterology 2009;136:99-107; quiz 352-3

107. Malamut G, Afchain P, Verkarre V, et al. Presentation and long-term follow-up of refractory celiac disease: comparison of type I with type II. Gastroenterology 2009;136:81-90.

108. Verbeek WH, Goerres MS, von Blomberg BM, et al. Flow cytometric determination of aberrant intra-epithelial lymphocytes predicts T-cell lymphoma development more accurately than T-cell clonality analysis in refractory celiac disease. Clin Immunol 2008;126:48-56.

109. Al-Toma A, Verbeek WH, Mulder CJ. Update on the management of refractory coeliac disease. J Gastrointestin Liver Dis 2007;16:57-63.

110. Maurino E, Niveloni S, Chernavsky AC, et al. Clinical characteristics and long-term outcome of patients with refractory sprue diagnosed at a single institution. Acta Gastroenterol Latinoam 2006;36:10-22. 
111. Daum S, Cellier C, Mulder CJ. Refractory coeliac disease. Best Pract Res Clin Gastroenterol 2005;19:413-24.

112. Biagi F, Corazza GR. Defining gluten refractory enteropathy. Eur J Gastroenterol Hepatol 2001;13:561-5.

113. Daum S, Weiss D, Hummel $\mathrm{M}$, et al. Frequency of clonal intraepithelial T lymphocyte proliferations in enteropathy-type intestinal T cell lymphoma, coeliac disease, and refractory sprue. Gut 2001:49:804-12

114. United European Gastroenterology. When is a coeliac a coeliac? Report of a working group of the United European Gastroenterology Week in Amsterdam, 2001. Eur J Gastroenterol Hepatol 2001:13:1123-8.

115. Cellier C, Delabesse E, Helmer C, et al. Refractory sprue, coeliac disease, and enteropathy-associated T-cell lymphoma. French Coeliac Disease Study Group. Lancet 2000;356:203-8.

116. Patey-Mariaud De Serre N, Cellier C, Jabri B, et al. Distinction between coeliac disease and refractory sprue: a simple immunohistochemical method. Histopathology 2000;37:70-7.

117. Bagdi E, Diss TC, Munson P, et al. Mucosal intra-epithelial lymphocytes in enteropathy-associated T-cell lymphoma, ulcerative jejunitis, and refractory celiac disease constitute a neoplastic population. Blood 1999;94:260-4.

118. Cellier C, Patey N, Mauvieux L, et al. Abnormal intestinal intraepithelial lymphocytes in refractory sprue. Gastroenterology 1998;114:471-81.

119. Fine KD, Meyer RL, Lee EL. The prevalence and causes of chronic diarrhea in patients with celiac sprue treated with a gluten-free diet. Gastroenterology 1997:112:1830-8.

120. Vahedi K, Mascart F, Mary JY, et al. Reliability of antitransglutaminase antibodies as predictors of gluten-free diet compliance in adult celiac disease. $A m \mathrm{~J}$ Gastroenterol 2003;98:1079-87.

121. Leffler DA, Dennis M, Hyett $\mathrm{B}$, et al. Etiologies and predictors of diagnosis in nonresponsive celiac disease. Clin Gastroenterol Hepatol 2007;5:445-50.

122. Fan $\mathbf{X}$, Sellin JH. Review article: small intestinal bacterial overgrowth, bile acid malabsorption and gluten intolerance as possible causes of chronic watery diarrhoea. Aliment Pharmacol Ther 2009;29:1069-77.

123. Abdulkarim AS, Burgart LJ, See J, et al. Etiology of nonresponsive celiac disease: results of a systematic approach. Am J Gastroenterol 2002;97:2016-21.

124. Johnston SD, Watson RG, Middleton D, et al. Genetic, morphometric and immunohistochemical markers of latent coeliac disease. Eur J Gastroenterol Hepatol 1999;11:1283-8

125. Meloni GF, Dessole S, Vargiu N, et al. The prevalence of coeliac disease in infertility. Hum Reprod 1999:14:2759-61.

126. Anon. National Institutes of Health Consensus Development Conference statement on celiac disease, June 28-30, 2004. Gastroenterology 2005;128(4 Suppl 1): S1-9.

127. Ludvigsson JF, Brandt L, Montgomery SM. Symptoms and signs in individuals with serology positive for celiac disease but normal mucosa. BMC Gastroenterol 2009;: 9:57.

128. Ludvigsson JF, Montgomery SM, Ekbom A, et al. Small-intestinal histopathology and mortality risk in celiac disease. JAMA 2009;302:1171-8.

129. Basso D, Guariso G, Fogar $\mathrm{P}$, et al. Antibodies against synthetic deamidated gliadin peptides for celiac disease diagnosis and follow-up in children. Clin Chem 2009:55:150-7.

130. Corazza GR, Andreani ML, Biagi F, et al. Clinical, pathological, and antibody pattern of latent celiac disease: report of three adult cases. Am J Gastroenterol 1996:91:2203-7.

131. Ferguson A, Blackwell JN, Barnetson RS. Effects of additional dietary gluten on the small-intestinal mucosa of volunteers and of patients with dermatitis herpetiformis. Scand J Gastroenterol 1987:22:543-9.

132. Murray IA, Smith JA, Coupland K, et al. Intestinal disaccharidase deficiency without villous atrophy may represent early celiac disease. Scand J Gastroenterol 2001;36:163-8.

133. Kurppa K, Ashorn M, Itanen $\mathrm{S}$, et al. Celiac disease without villous atrophy in children: a prospective study. J Pediatr 2010:157:373-80, 380.e1.

134. Kurppa K, Collin P, Viljamaa M, et al. Diagnosing mild enteropathy celiac disease: a randomized, controlled clinical study. Gastroenterology 2009;136:816-23.

135. Freeman HJ, Chiu BK. Multifocal small bowel lymphoma and latent celiac sprue. Gastroenterology 1986;90:1992-7.

136. Hovdenak N, Hovlid E, Aksnes L, et al. High prevalence of asymptomatic coeliac disease in Norway: a study of blood donors. Eur J Gastroenterol Hepatol 1999;11:185-7.

137. Moayyedi $\mathbf{P}, O^{\prime}$ Mahony $S$, Jackson $P$, et al. Small intestine in lymphocytic and collagenous colitis: mucosal morphology, permeability, and secretory immunity to gliadin. J Clin Pathol 1997:50:527-9.

138. Biagi F, Luinetti 0 , Campanella J, et al. Intraepithelial lymphocytes in the villous tip: do they indicate potential coeliac disease? J Clin Pathol 2004;57:835-9.

139. Arranz E, Bode J, Kingstone $K$, et al. Intestinal antibody pattern of coeliac disease: association with gamma/delta T cell receptor expression by intraepithelial lymphocytes, and other indices of potential coeliac disease. Gut 1994;35:476-82.

140. Maki M, Holm K, Collin P, et al. Increase in gamma/delta T cell receptor bearing lymphocytes in normal small bowel mucosa in latent coeliac disease. Gut 1991;32:1412-14.

141. Maki M, Huupponen T, Holm K, et al. Seroconversion of reticulin autoantibodies predicts coeliac disease in insulin dependent diabetes mellitus. Gut 1995;36:239-42.
142. Ferguson A, Arranz E, O'Mahony S. Clinical and pathological spectrum of coeliac disease - active, silent, latent, potential. Gut 1993;34:150-1.

143. Lebwohl B, Kapel RC, Neugut Al, et al. Adherence to biopsy guidelines increases celiac disease diagnosis. Gastrointest Endosc 2011;74:103-9.

144. Hummel S, Hummel M, Banholzer J, et al. Development of autoimmunity to transglutaminase $\mathrm{C}$ in children of patients with type 1 diabetes: relationship to islet autoantibodies and infant feeding. Diabetologia 2007;50:390-4.

145. Liu E, Li M, Emery L, et al. Natural history of antibodies to deamidated gliadin peptides and transglutaminase in early childhood celiac disease. J Pediatr Gastroenterol Nutr 2007;45:293-300.

146. Simmons JH, Klingensmith GJ, McFann K, et al. Impact of celiac autoimmunity on children with type 1 diabetes. J Pediatr 2007:150:461-6.

147. Diniz-Santos DR, Brandao F, Adan L, et al. Bone mineralization in young patients with type 1 diabetes mellitus and screening-identified evidence of celiac disease. Dig Dis Sci 2008:53:1240-5.

148. De Block CE, De Leeuw IH, Vertommen JJ, et al. Beta-cell, thyroid, gastric, adrenal and coeliac autoimmunity and HLA-DQ types in type 1 diabetes. Clin Exp Immunol 2001;126:236-41.

149. Catassi C, Kryszak D, Bhatti B, et al. Natural history of celiac disease autoimmunity in a USA cohort followed since 1974. Ann Med 2010;42:530-8.

150. Stene LC, Honeyman MC, Hoffenberg EJ, et al. Rotavirus infection frequency and risk of celiac disease autoimmunity in early childhood: a longitudinal study. Am J Gastroenterol 2006;101:2333-40.

151. Norris JM, Barriga K, Hoffenberg EJ, et al. Risk of celiac disease autoimmunity and timing of gluten introduction in the diet of infants at increased risk of disease. JAMA 2005;293:2343-51.

152. Dezsofi A, Szebeni B, Hermann CS, et al. Frequencies of genetic polymorphisms of TLR4 and CD14 and of HLA-DQ genotypes in children with celiac disease, type 1 diabetes mellitus, or both. J Pediatr Gastroenterol Nutr 2008;47:283-7.

153. Fasano A. Celiac disease-how to handle a clinical chameleon. N Engl J Med 2003;348:2568-70.

154. van Heel DA, Franke L, Hunt KA, et al. A genome-wide association study for celiac disease identifies risk variants in the region harboring IL2 and IL21. Nat Genet 2007:39:827-9.

155. Newnham ED. Does gluten cause gastrointestinal symptoms in subjects without coeliac disease? J Gastroenterol Hepatol 2011;26(Suppl 3):132-4.

156. Biesiekierski JR, Newnham ED, Irving PM, et al. Gluten causes gastrointestinal symptoms in subjects without celiac disease: a double-blind randomized placebo-controlled trial. Am J Gastroenterol 2011:106:508-14; quiz 515. doi:10.1038/ajg.2010.487

157. Bizzaro N, Tozzoli R, Villatta D, et al. Cutting-edge issues in celiac disease and in gluten intolerance. Clin Rev Allergy Immunol. Published Online First: 23 December 2010.

158. Poloni N, Vender S, Bolla E, et al. Gluten encephalopathy with psychiatric onset: case report. Clin Pract Epidemiol Ment Health 2009;5:16.

159. Cascella NG, Kryszak D, Bhatti B, et al. Prevalence of celiac disease and gluten sensitivity in the United States clinical antipsychotic trials of intervention effectiveness study population. Schizophr Bull 2011;37:94-100.

160. Ozdemir 0, Mete E, Catal F, et al. Food intolerances and eosinophilic esophagitis in childhood. Dig Dis Sci 2009;54:8-14.

161. Llorente-Alonso MJ, Fernandez-Acenero MJ, Sebastian M. Gluten intolerance: sex and age-related features. Can J Gastroenterol 2006;20:719-22.

162. Humbert P, Pelletier F, Dreno B, et al. Gluten intolerance and skin diseases. Eur $J$ Dermatol 2006;16:4-11.

163. Kalaydjian AE, Eaton W, Cascella N, et al. The gluten connection: the association between schizophrenia and celiac disease. Acta Psychiatr Scand 2006:113:82-90.

164. Sblattero D, Ventura A, Tommasini A, et al. Cryptic gluten intolerance in type 1 diabetes: identifying suitable candidates for a gluten free diet. Gut 2006;55:133-4.

165. Helms S. Celiac disease and gluten-associated diseases. Altern Med Rev 2005:10:172-92.

166. Gobbi G. Coeliac disease, epilepsy and cerebral calcifications. Brain Dev 2005:27:189-200

167. Volta U, De Giorgio R, Petrolini N, et al. Clinical findings and anti-neuronal antibodies in coeliac disease with neurological disorders. Scand J Gastroenterol 2002; 37:1276-81.

168. Leggio L, Abenavoli L, D'Angelo C, et al. Gluten-related cerebral hypoperfusion and neurologic disorders in coeliac patients. Aliment Pharmacol Ther 2004;20:821-2; author reply 822.

169. Sardy M, Karpati S, Merkl B, et al. Epidermal transglutaminase (TGase 3) is the autoantigen of dermatitis herpetiformis. J Exp Med 2002;195:747-57.

170. Hadjivassiliou M, Grunewald RA, Chattopadhyay AK, et al. Clinical, radiological, neurophysiological, and neuropathological characteristics of gluten ataxia. Lancet 1998; $352: 1582-5$

171. Troncone R, Jabri B. Coeliac disease and gluten sensitivity. J Intern Med 2011;269:582-90.

172. Massari S, Liso M, De Santis L, et al. Occurrence of nonceliac gluten sensitivity in patients with allergic disease. Int Arch Allergy Immunol 2011;155:389-94.

173. Sapone A, Lammers KM, Casolaro V, et al. Divergence of gut permeability and mucosal immune gene expression in two gluten-associated conditions: celiac disease and gluten sensitivity. BMC Med 2011;9:23.

174. Sapone A, Lammers KM, Mazzarella G, et al. Differential mucosal IL-17 expression in two gliadin-induced disorders: gluten sensitivity and the autoimmune enteropathy celiac disease. Int Arch Allergy Immunol 2010;152:75-80. 
175. Verdu EF. Editorial: Can gluten contribute to irritable bowel syndrome? Am J Gastroenterol 2011;106:516-18.

176. de Magistris L, Familiari V, Pascotto A, et al. Alterations of the intestinal barrier in patients with autism spectrum disorders and in their first-degree relatives. J Pediatr Gastroenterol Nutr 2010;51:418-24

177. Signer $\mathbf{E}$, Burgin-Wolff A, Berger R, et al. Antibodies to gliadin as a screening test for coeliac disease. A prospective study. Helv Paediatr Acta 1979;34:41-52.

178. O'Farrelly C, Kelly J, Hekkens W, et al. Alpha gliadin antibody levels: a serological test for coeliac disease. Br Med J (Clin Res Ed) 1983;286:2007-10.

179. Leffler DA, Schuppan D. Update on serologic testing in celiac disease. Am J Gastroenterol 2010;105:2520-4.

180. Lagerqvist C, Dahlbom I, Hansson T, et al. Antigliadin immunoglobulin A best in finding celiac disease in children younger than 18 months of age. J Pediatr Gastroenterol Nutr 2008;47:428-35.

181. Schwertz E, Kahlenberg F, Sack U, et al. Serologic assay based on gliadin-related nonapeptides as a highly sensitive and specific diagnostic aid in celiac disease. Clin Chem 2004:50:2370-5.

182. Osman AA, Uhlig HH, Valdes I, et al. A monoclonal antibody that recognizes a potential coeliac-toxic repetitive pentapeptide epitope in gliadins. Eur J Gastroenterol Hepatol 2001:13:1189-93.

183. Mendez E, Vela C, Immer U, et al. Report of a collaborative trial to investigate the performance of the R5 enzyme linked immunoassay to determine gliadin in glutenfree food. Eur J Gastroenterol Hepatol 2005;17:1053-63.

184. Burgin-Wolff A, Gaze H, Hadziselimovic F, et al. Antigliadin and antiendomysium antibody determination for coeliac disease. Arch Dis Child 1991:66:941-7.

185. Dieterich W, Ehnis $\mathrm{T}$, Bauer $\mathbf{M}$, et al. Identification of tissue transglutaminase as the autoantigen of celiac disease. Nat Med 1997;3:797-801.

186. Sulkanen S, Halttunen T, Laurila $\mathrm{K}$, et al. Tissue transglutaminase autoantibody enzyme-linked immunosorbent assay in detecting celiac disease. Gastroenterology 1998;115:1322-8.

187. Dieterich W, Laag E, Schopper H, et al. Autoantibodies to tissue transglutaminase as predictors of celiac disease. Gastroenterology 1998;115:1317-21.

188. Hadithi M, von Blomberg BM, Crusius JB, et al. Accuracy of serologic tests and HLA-DO typing for diagnosing celiac disease. Ann Intern Med 2007; 147:294-302

189. Cooke WT, Smith WT. Neurological disorders associated with adult coeliac disease. Brain 1966:89:683-722.

190. Hadjivassiliou M, Sanders DS, Grunewald RA, et al. Gluten sensitivity: from gut to brain. Lancet Neurol 2010:9:318-30.

191. Burk K, Farecki ML, Lamprecht G, et al. Neurological symptoms in patients with biopsy proven celiac disease. Mov Disord 2009;24:2358-62.

192 Hadjivassiliou M, Aeschlimann P. Strigun A, et al. Autoantibodies in gluten ataxia recognize a novel neuronal transglutaminase. Ann Neurol 2008;64:332-43.

193. Boscolo S, Sarich A, Lorenzon A, et al. Gluten ataxia: passive transfer in a mouse model. Ann N Y Acad Sci 2007:1107:319-28.
194. Ihara M, Makino F, Sawada H, et al. Gluten sensitivity in Japanese patients with adult-onset cerebellar ataxia. Intern Med 2006;45:135-40.

195. Hadjivassiliou M, Maki M, Sanders DS, et al. Autoantibody targeting of brain and intestinal transglutaminase in gluten ataxia. Neurology 2006:66:373-7.

196. Hadjivassiliou M, Davies-Jones GA, Sanders DS, et al. Dietary treatment of gluten ataxia. J Neurol Neurosurg Psychiatry 2003;74:1221-4.

197. Abele M, Schols L, Schwartz S, et al. Prevalence of antigliadin antibodies in ataxia patients. Neurology 2003;60:1674-5.

198. Hadjivassiliou M, Grunewald R, Sharrack B, et al. Gluten ataxia in perspective: epidemiology, genetic susceptibility and clinical characteristics. Brain 2003;126:685-91.

199. Luostarinen LK, Collin PO, Peraaho MJ, et al. Coeliac disease in patients with cerebellar ataxia of unknown origin. Ann Med 2001;33:445-9.

200. van der Meer JB. Granular deposits of immunoglobulins in the skin of patients with dermatitis herpetiformis. An immunofluorescent study. $\mathrm{Br} J$ Dermatol 1969;81:493-503

201. Meyer LJ, Carioto L, Zone JJ. Dermatitis herpetiformis: extraction of intact $\lg A$ from granular deposits in dermal papillae. J Invest Dermatol 1987:88:559-63.

202. Zone JJ, Meyer LJ, Petersen MJ. Deposition of granular IgA relative to clinical lesions in dermatitis herpetiformis. Arch Dermatol 1996;132:912-18.

203. Fry L, Keir P, McMinn RM, et al. Small-intestinal structure and function and haematological changes in dermatitis herpetiformis. Lancet 1967;2:729-33.

204. Fry L, Seah PP, Harper PG, et al. The small intestine in dermatitis herpetiformis. J Clin Pathol 1974;27:817-24.

205. Bolotin D, Petronic-Rosic V. Dermatitis herpetiformis. Part I. Epidemiology, pathogenesis, and clinical presentation. J Am Acad Dermatol 2011;64:1017-24; quiz 1025-6

206. Fry L, Seah PP, Riches DJ, et al. Clearance of skin lesions in dermatitis herpetiformis after gluten withdrawal. Lancet 1973;1:288-91.

207. Leonard J, Haffenden G, Tucker W, et al. Gluten challenge in dermatitis herpetiformis. N Engl J Med 1983:308:816-19.

208. Reunala T, Blomqvist K, Tarpila S, et al. Gluten-free diet in dermatitis herpetiformis. I. Clinical response of skin lesions in 81 patients. Br J Dermatol 1977:97:473-80.

209. Garioch JJ, Lewis HM, Sargent SA, et al. 25 years' experience of a gluten-free diet in the treatment of dermatitis herpetiformis. Br J Dermatol 1994;131:541-5.

210. Smith JB, Tulloch JE, Meyer LJ, et al. The incidence and prevalence of dermatitis herpetiformis in Utah. Arch Dermatol 1992;128:1608-10.

211. Hardman CM, Garioch JJ, Leonard JN, et al. Absence of toxicity of oats in patient with dermatitis herpetiformis. N Engl J Med 1997;337:1884-7.

212. Collin P, Reunala T. Recognition and management of the cutaneous manifestations of celiac disease: a guide for dermatologists. Am J Clin Dermatol 2003;4:13-20.

213. Caproni M, Antiga E, Melani L, et al. Guidelines for the diagnosis and treatment of dermatitis herpetiformis. J Eur Acad Dermatol Venereol 2009;23:633-8.

214. Collin P, Pukkala E, Reunala T. Malignancy and survival in dermatitis herpetiformis: a comparison with coeliac disease. Gut 1996:38:528-30. 